\title{
Synthesis of intrathecal interferon in systemic lupus erythematosus with neurological complications
}

\author{
P LEBON, G R LENOIR, A FISCHER, A LAGRUE
}

\begin{abstract}
Intrathecal synthesis of interferon in the absence of viral or bacterial infection was detected during the occurrence of neurological complications in two patients with systemic lupus erythematosus. The interferons displayed characteristics similar to those observed in the sera of patients with the disease. No interferon inducing activity was detected in the cerebrospinal fluid or serum of the two patients.

These observations support the hypothesis of a localised mechanism of interferon induction in systemic lupus erythematosus which includes the interaction of lymphocytes with damaged tissues.
\end{abstract}

\section{Introduction}

$\alpha$ Interferon is produced by non- $\mathrm{T}^{1}$ and non- $\mathrm{B}^{2}{ }^{3}$ lymphocytes and monocytes. ${ }^{3}$ In man these cells may be induced by infectious or inactivated viruses ${ }^{4}$ or after contact with virus infected and glutaraldehyde fixed cells. ${ }^{6}$ In some tissues-for example, embryonic fibroblasts and amniotic membranes $-\alpha$ interferon may be synthesised simultaneously with $\beta$ interferon. ${ }^{78}$

Recent studies show that during the acute phase of systemic lupus erythematosus high levels of an $\alpha$ interferon ( $\mathrm{pH} 2$ labile) may be detected in the sera of more than $70 \%$ of patients. ${ }^{9-13}$ The role of interferon and the induction mechanism in this disease are unknown. Leucocytes from patients secreting interferon do not release $\alpha$ interferon spontaneously in vitro ${ }^{14}$

\section{INSERM U43, Hôpital Saint Vincent-de Paul, 75014 Paris P LEBON, MD, virologist}

Hôpital des Enfants Malades, 75015 Paris

G R LENOIR, MD, assistant professor, clinique des maladies des enfants, INSERM U30

A FISCHER, MD, department of paediatrics, INSERM U132

A LAGRUE, MD, department of paediatrics, INSERM U132

Correspondence to: Dr P Lebon. but can be induced for the synthesis of $\gamma$ interferon. ${ }^{11}$ These findings suggest that the $\alpha$ interferon detected in the serum of these patients may be produced by tissue bound lymphocytes rather than by circulating cells. We confirm and extend this hypothesis by describing the synthesis of interferon localised in the central nervous system of two patients with systemic lupus erythematosus.

\section{Patients and methods}

Case 1-A 7 year old girl with a two month history of systemic lupus erythematosus, developed seizures of the right side and coma for four weeks, associated with fever, facies erythematosus, and conjunctivitis. No immunosuppressive drugs had been given before the onset of the neurological symptoms. The electroencephalogram at first showed non-periodic complexes, then slow waves. The neurological symptoms resolved completely within one month with intravenous corticosteroids. The diagnosis of lupus was based on an antinuclear antibody titre exceeding $1 / 1000$ with a speckled pattern and an anti-DNA antibody titre of 59 (normal $<20$ ).

Case 2-A 14 year old girl was admitted for weight loss and lethargy after a one year history of systemic lupus erythematosus. Neurological findings were normal. The electroencephalogram, however, showed slow waves in the rolandotemporal regions, and analysis of the cerebrospinal fluid disclosed meningitis. She had not been given immunosuppressive drugs before the onset of these symptoms. Treatment with corticosteroids was instituted, and after a short period of hallucinations all the symptoms disappeared. The diagnosis of the relapse of lupus was based on an antinuclear antibody titre exceeding $1 / 1000$ with a speckled pattern and an anti-DNA antibody titre of 56 .

\section{STUDY PROCEDURES}

Samples of cerebrospinal fluid were assayed for virus isolation in human diploid (MRC 5) cells, KB cells, and primary African green monkey cells-all routinely kept in the laboratory.

Serum and cerebrospinal fluid antibodies were tested by microassays, cytopathic effect neutralisation, complement fixation, and haemagglutination inhibition. Measles, rubella, and mumps IgM antibodies were sought by haemagglutination inhibition after separation from the sera by ultracentrifugation on sucrose gradients.

Interferon was assayed on bovine cells sensitive to $\alpha$ interferon (MDBK) and challenged with vesicular stomatitis virus, as described. ${ }^{5}$ 
Interferon antibodies were tested in sera and cerebrospinal fluid collected during convalescence: $100 \mu 1$ sera (diluted $1 / 4$ ) and cerebrospinal fluid (diluted 1/2) were added to $100 \mathrm{IU}$ interferon $(100 \mu \mathrm{l})$. The mixture was incubated for one hour at $37^{\circ} \mathrm{C}$ and for the next hour at $4^{\circ} \mathrm{C}$ and the residual activity of interferon titrated in MDBK cells.

Serum and cerebrospinal fluid interferons were also titrated after dialysis for 24 hours with two changes of $0.1 \mathrm{M}$ glycine buffer adjusted to $\mathrm{pH}$ 2. They were then typed with sheep anti- $\alpha$ interferon (Dr C Chany), rabbit anti- $\beta$ interferon (Dr J Vilcek), and anti- $\gamma$ interferon (J Johnson, J Stanton) sera.

Serum and cerebrospinal fluid containing interferon were tested for their ability to induce $\alpha$ interferon in lymphocytes from healthy donors: $100 \mu \mathrm{l}$ samples were incubated with $1 \mathrm{ml}$ lymphocytes $\left(10^{6} \mathrm{cells} / \mathrm{ml}\right)$ at $37^{\circ} \mathrm{C}$ for one to five days. Sendai virus (E72 strain) and herpesvirus (type I) were used as controls. The supernatants were tested for the presence of interferon by assay using MDBK cells before and after $\mathrm{pH} 2$ treatment.

\section{Results}

Neither virus nor bacteria were detected in the cerebrospinal fluid samples. Serological tests did not show a rise of antibody titre in either of two sera from each patient or in cerebrospinal fluid against mycoplasma and the following common neuropathogenic viruses: herpes, varicella, mumps, measles, Epstein-Barr, cytomegalovirus, Coxsackie $\mathrm{B}$, influenzae $\mathrm{A}$ and $\mathrm{B}$, adenovirus, and respiratory syncytial virus. Measles, rubella, and mumps IgM antibodies were not detected in the sera. Large amounts of interferon, however, were detected in the first cerebrospinal fluid sample from these two patients. The interferon disappeared 15 days later (table).

Presence of interferon in cerebrospinal fluid and serum

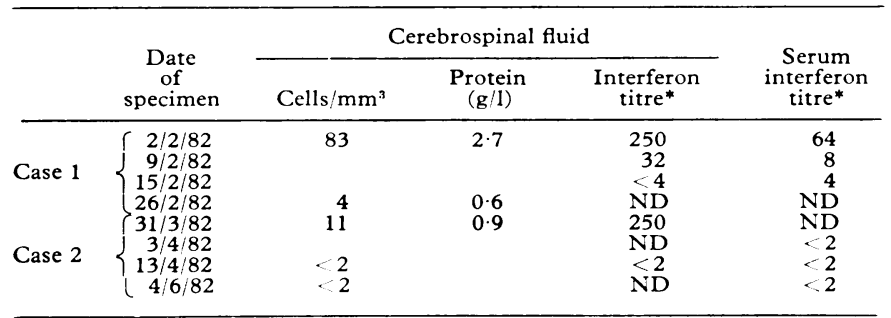

ND $=$ Not done.
*Titre expressed in international reference units (IU).

In case 1 interferon was also present in the serum but at a lesser concentration. In case 2 interferon was not detected in serum taken four days after the collection of cerebrospinal fluid.

The antiviral activity of this interferon was neutralised by anti- $\alpha$ but not by anti- $\beta$ or anti- $\gamma$ interferon sera. It was partially inhibited by $\mathrm{pH} 2$ treatment (data not shown). No anti- $\alpha$ interferon activity was detected in serum or cerebrospinal fluid taken at two weeks (case 1) or two months (case 2) in the course of the disease.

The first cerebrospinal fluid and serum samples collected from both patients had no interferon inducing activity after contact with lymphocytes of healthy donors.

\section{Discussion}

The presence of high concentrations of interferon in the cerebrospinal fluid of children with acute encephalopathies is a rare phenomenon (only $10 \%$ of cases; P Lebon, unpublished), generally not observed in postinfectious encephalitis but associated only with primary encephalitis (K Hamano et al, submitted for publication). ${ }^{15-18}$ None of the most important neuropathogenic viruses could be implicated in the neurological complications of the two children in our study despite the presence of intrathecal interferon. In both cases cerebrospinal fluid $\alpha$ interferon was slightly inactivated when treated at $\mathrm{pH} 2$ and differed in this respect from the variant detected in herpes encephalitis. It was, however, neutralised by serum containing anti- $\alpha$ interferon but not by serum containing anti- $\beta$ or anti- $\gamma$ interferon. These characteristics are similar to those of interferons reported in the serum in systemic lupus erythematosus. ${ }^{11}$

In our two cases interferon was predominantly synthesised in the central nervous system, the intrathecal values being higher than those in the serum. Direct production of $\alpha$ interferon by cells of the central nervous system other than leucocytes due to an infectious virus was not likely since it was not associated with synthesis of $\beta$ interferon. Probably also induction could not be attributed to an intrathecal soluble antigen, since spinal fluids themselves tapped at the onset of the neurological symptoms did not induce any interferon in lymphocytes from healthy donors (data not shown).

The intrathecal synthesis of $\alpha$ interferon in these patients may be attributed to the expression of new antigens in the membrane of local cells. These might induce interferon after contact with the membrane of lymphocytes. Such a mechanism of induction has been shown in vitro: indeed, human $\alpha$ interferon may be induced after interaction of blood mononuclear cells with transformed cells ${ }^{19}$ or with glutaraldehyde fixed herpesvirus infected cells, but not with uninfected fibroblasts. A similar process of induction has also been observed in vivo: at the onset of herpes encephalitis intrathecal interferon almost invariably present in the cerebrospinal fluid ${ }^{1618}$ was induced by viral antigens bound to the nervous tissue. Indeed, soluble viral antigens are rarely detected in the spinal fluid by radioimmunoassay or enzyme immunoassay.

These observations confirm that the interferon in the course of systemic lupus erythematosus is produced by organ bound lymphocytes, as suggested. ${ }^{11}$ If such an induction mechanism as the one proposed here occurs in this disease, $\alpha$ interferon and especially the $\mathrm{pH} 2$ sensitive variant could be used in vitro as a marker to detect foreign antigens or biochemical modifications in the cell membrane of damaged tissues.

It is now well documented that interferons increase the severity of autoimmune disease in NZB mice. ${ }^{20-22}$ Some pathological changes characteristic of systemic lupus erythematosus might also be related to the presence of interferons in serum and cerebrospinal fluid. Thus the favourable outcome in both of our cases after intravenous administration of corticosteroids might have been attributable to the suppressive effect of these drugs on the production of $\alpha$ interferon.

\section{References}

${ }^{1}$ Yamaguchi K, Handa Y, Shimizu Y, Abo T, Kumagin K. Target cells for interferon production in human leukocytes stimulated by Senda virus. F Immunol 1977;118:1931-5.

${ }^{2}$ Kirchner H, Peter H, Hirt HM, Zawatsky R, Dalugge H, Bradstreet $\mathbf{P}$ Studies of the producer cell of interferon in human lymphocyte cultures. Immunobiology 1979;156:65-75.

${ }^{3}$ Lebon P, Bernard A, Boumsell L. Identification de populations lymphocytaires productrices d'interféron- $\alpha$ par des anticorps monoclonaux. C R Acad Sci (Paris) $1982 ; 295: 79-82$.

- Haar S, Rasmussen L, Merigan T. Lymphocyte transformation and IFN production in human mononuclear cell microcultures for assay of cellular immunity to herpes simplex virus. Infect Immun 1976;14: 47-54.

${ }^{5}$ Lebon P, Commoy-Chevalier MJ, Robert-Galliot B, Morin A. Production d'interféron humain de type I par des lymphocytes au contact de cellules infectées par le virus herpès et fixées par le glutaraldehyde. $C R$ Acad Sci (Paris) 1980;290:37-40.

${ }^{6}$ Lebon P, Commoy-Chevalier MJ, Robert-Galliot B, Chany C. Different mechanisms for $\alpha$ and $\beta$ interferon induction. Virology 1982;119: 504-7.

${ }^{7}$ Havell EA, Hayes TG, Vilcek J. Synthesis of two distinct interferons by human fibroblasts. Virology 1978;89:330-4.

8 Duc-Goiran P, Robert-Galliot B, Chudzio T, Chany C. Unusual human interferons produced by virus-infected amniotic membranes. Proc Natl Acad Sci USA (in press)

${ }^{9}$ Skurkovich S, Eremkina EI. The probable role of interferon in allergy. Ann Allergy 1975;35:356-60.

${ }^{10}$ Hooks JJ, Moutsopoulos HM, Geis SA, Stahl NI, Decker JL, Notkin AL. Immune interferon in the circulation of patients with autoimmune disease. $N$ Engl f Med 1979;301:5-8. 
11 Preble OT, Black RJ, Friedman RM, Klippel JH, Vilcek J. Systemic lupus erythematosus: presence in human serum of an unusual acidlabile leukocyte interferon. Science $1982 ; 216: 429-31$.

12 Ytterberg SR, Schnitzer TJ. Serum interferon levels in patients with systemic lupus erythematosus. Arthritis Rheum 1982;25:401-6.

${ }^{13}$ Hooks JJ, Jordan GW, Cupps T, Moutsopoulos HM, Fauci AS, Notkins AL. Multiple interferons in the circulation of patients with systemic lupus erythematosus and vasculitis. Arthritis Rheum $1982 ; 25: 396-400$.

${ }_{14}$ Neighbour PA, Grayzel AE. Interferon production in vitro by leukocytes from patients with systemic lupus erythematosus and rheumatoid arthritis. Clin Exp Immunol 1981;45:576-81.

${ }^{15}$ Luby JP, Sanders CV, Sulkin SE. Interferon assays and quantitative virus determination in a fatal infection in man with Western equine encephalomyelitis virus. Am 7 Trop Med Hyg 1971 ;20:765-9.

16 Lebon P, Ponsot G, Aicardi J, Goutières F, Arthuis M. Early intrathecal synthesis of interferon in herpes encephalitis. Biomedicine 1979;31: 267-71

${ }^{17}$ Legaspi RC, Gatmaitan B, Bailey EJ, Lerner AM. Interferon in biopsy and autopsy specimens of brain: its presence in herpes simplex virus encephalitis. Arch Neurol 1980;37:76-9.

18 Vézinet F, Lebon P, Amoudry C, Gibert C. Sythèse d'interféron au cours des encéphalites herpétiques de l'adulte. Presse Médicale 1981;10: 1135-8.

19 Trinchieri G, Santoli D, Knowles BB. Tumour cell lines induce interferon in human lymphocytes. Nature 1977;270:611-3.

${ }^{20}$ Heremans H, Billiau A, Colombatti A, Hilgers J, De Somer P. Interferon treatment of NZB mice: accelerated progression of autoimmune disease. Infect Immun 1978;21:925.

${ }^{21}$ Sergiescu D, Cerutti I, Efthymiou E, Kahan A, Chany C: Adverse effects of interferon treatment on the life span of NZB mice. Biomedicine $1979 ; 31: 48-51$.

${ }^{22}$ Adam C, Thoua Y, Ronco P, Verroust P, Tovey M, Morel-Maroger L. The effect of exogenous interferon: acceleration of autoimmune and renal diseases in NZB/W F1 mice. Clin Exp Immunol 1980;40:373-82.

(Accepted 22 fuly 1983)

\title{
Ulceration of the hand secondary to a radial arteriovenous fistula: a model for varicose ulceration
}

\author{
M L WOOD，G D REILLY，G T SMITH
}

\begin{abstract}
A patient in whom a radial arteriovenous fistula was constructed in preparation for haemodialysis subsequently developed ulceration on the dorsum of the hand. The lesion failed to heal despite antibiotic treatment, and so the fistula was closed. The lesion healed within three weeks. Subsequent construction of a fistula at the right wrist was followed 12 months later by the development of similar ulceration of the right hand.

This complication of arteriovenous fistulas is similar to varicose ulceration of the leg and provides a unique opportunity to study the effects of sustained venous hypertension on the skin.
\end{abstract}

\section{Introduction}

Ulceration of the hand may develop as a complication of arteriovenous fistulas. We report on a patient with this complication.

\section{Case report}

A side to side arteriovenous fistula was constructed at the left wrist between the dorsal radial artery and vein in preparation for haemodialysis in a 48 year old woman with chronic renal failure secondary to diabetic nephropathy. Her renal failure was managed conservatively, and the blood urea concentration remained raised at around $40 \mathrm{mmol} / \mathrm{l}$ $(240 \mathrm{mg} / 100 \mathrm{ml})$. Eighteen months later she presented to the dermatology outpatients department with swelling of the left hand and an erythematous and indurated area on the dorsum of the hand between

\footnotetext{
Rupert Hallam Department of Dermatology, Royal Hallamshire Hospital, Sheffield S10 2JF

$M$ L WOOD, MB, MRCP, senior registrar

G D REILLY, MA, MRCP, registrar

Department of Pathology, Royal Hallamshire Hospital

G T SMITH, MB, MRCPATH, lecturer

Correspondence to: Dr M L Wood.
}

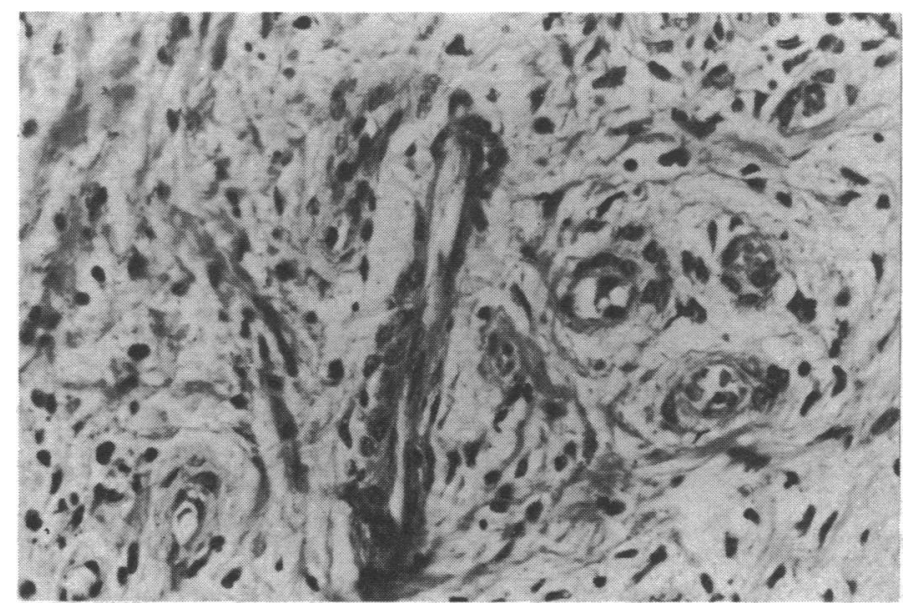

Biopsy specimen showing thick walled capillaries with plump endothelial cells in upper dermis. Haematoxylin and eosin $\times 210$.

the thumb and the index finger, which had been present for about six months. She was not feverish and was otherwise well.

A skin swab grew Staphylococcus pyogenes, and she was given a course of oral erythromycin $250 \mathrm{mg}$ four times a day. The lesion failed to heal, and a small ulcer developed over the proximal phalanx of the index finger. A biopsy specimen of the edge of the ulcer (figure) showed thick walled capillaries with plump endothelial cells in a mildly oedematous dermis. Larger vessels showed intimal proliferation. The thickened eosinophilic capillary walls and pericapillary tissue showed focal positive staining for fibrin by the peroxidase antiperoxidase technique. There was a light mixed inflammatory cell infiltrate including eosinophils in the dermis.

Because of the persisting ulceration the fistula at the left wrist was closed; within three weeks the lesion had healed. A further fistula was fashioned at the right wrist, and 12 months later she began to develop a similar erythematous, indurated area on the dorsum of the right hand.

\section{Discussion}

Ulceration of the hand as a complication of arteriovenous fistulas has been described previously. ${ }^{1}$ It is thought to result from retrograde venous arterialisation, the high pressure in the 